\title{
Clinicopathological and molecular characterization of nine cases of columnar cell variant of papillary thyroid carcinoma
}

\author{
Jey-Hsin Chen ${ }^{1,2}$, William C Faquin ${ }^{3}$, Ricardo V Lloyd ${ }^{4,5}$ and Vânia Nosée ${ }^{1,6}$ \\ ${ }^{1}$ Department of Pathology, Brigham and Women's Hospital, Boston, MA, USA; ${ }^{2}$ Department of Pathology and \\ Laboratory Medicine, Indiana University School of Medicine, Indianapolis, IN, USA; ${ }^{3}$ Department of \\ Pathology, Massachusetts General Hospital, Harvard Medical School, Boston, MA, USA; ${ }^{4}$ Department of \\ Laboratory Medicine and Pathology, Mayo Clinic Rochester, Rochester, MN, USA; ${ }^{5}$ Department of Pathology \\ and Laboratory Medicine, University of Wisconsin School of Medicine and Public Health, Madison, WI, USA \\ and ${ }^{6}$ Department of Pathology, University of Miami Leonard M Miller School of Medicine, Miami, FL, USA
}

\begin{abstract}
The majority of papillary thyroid carcinoma is indolent and associated with long-term survival. The columnar cell variant, however, is a rare subtype that is variable in biological behavior; some are clinically aggressive, whereas others are more clinically indolent. Tumor size, tumor circumscription, and encapsulation may influence the behavior of columnar cell carcinomas. Other variables including genetic changes and putative biomarkers associated with malignant growth have not been thoroughly examined in these neoplasms. In this study, nine cases of columnar cell variant of papillary thyroid carcinoma from three institutions were classified as clinically indolent or aggressive based on pathological features, clinical history, and outcome. Indolent tumors were typically small, circumscribed or encapsulated, and from younger female patients, whereas aggressive tumors were large, locally aggressive, associated with regional and distant metastasis, and from older male patients. The missense mutation, V600E in the BRAF oncogene (BRAF ${ }^{\mathrm{V} 600 \mathrm{~F}}$ ), was detected in three of nine of cases, of which two were clinically aggressive. Immunohistochemical evaluation of neoplasiaassociated markers showed increased nuclear cyclin D1 expression, elevated Ki-67 proliferation indices, and predominantly weak nuclear p53 staining in both indolent and aggressive tumors. Expression of $\beta$-catenin was largely restricted to a membranous pattern in both tumor types. Cytoplasmic expression of bcl-2 was overall mildly reduced in indolent neoplasms. Nuclear expression of estrogen and progesterone receptors was increased in both indolent and aggressive neoplasms, but was without sex- or age-related differences; however, whereas progesterone receptor expression was diffuse and strong in clinically indolent carcinomas, its expression was diminished in aggressive neoplasms. Recognition of the clinicopathological characteristics and the molecular and immunophenotypic features of the columnar cell variant of papillary thyroid carcinoma may aid in characterizing neoplasms that behave indolently or aggressively. Modern Pathology (2011) 24, 739-749; doi:10.1038/modpathol.2011.2; published online 25 February 2011
\end{abstract}

Keywords: $B R A F\left(B R A F^{V 6 O O E}\right) ; \beta$-catenin; columnar cell variant; cyclin $\mathrm{D} 1$; papillary thyroid carcinoma

Papillary thyroid carcinoma is a common endocrine neoplasm that is typically indolent and associated with long-term survival. This favorable biological behavior reflects the vast majority of conventional

Correspondence: Dr V Nosé, MD, PhD, Department of Pathology (R-5), University of Miami Miller School of Medicine, 1120 NW 14th Avenue, Room 1411, Miami, FL 33136, USA.

E-mail: vnose@med.miami.edu

Received 16 June 2010; revised 2 October 2010; accepted 2 October 2010; published online 25 February 2011 and histological variants of well-differentiated papillary thyroid carcinoma. However, a more aggressive tumoral growth characterizes a small subset that behaves more akin to poorly differentiated and undifferentiated thyroid carcinoma. Initially included in this group of aggressive neoplasms, the columnar cell variant is a rare subtype with variable biological behavior. Early reports described tumors with fast growth rates, aggressive local invasion, high rates of recurrence, early metastasis to regional lymph nodes and distant 
visceral sites, and fatality as a result of the disease..$^{1-6}$ However, the notion that these neoplasms are clinically aggressive was later challenged by observations that tumor circumscription and/or encapsulation may confer a more favorable outcome. ${ }^{7-9}$

Genetic alterations resulting in the activation of the receptor tyrosine kinase signaling cascade are found in the majority of well-differentiated papillary thyroid carcinomas. ${ }^{10,11}$ The most common genetic change is a missense mutation, V600E (single letter amino acid), in the gene encoding the serine/threonine kinase, $b$-raf $\left(B R A F^{V 600 E}\right) .{ }^{12-15}$ This mutation results in constitutive activation of the kinase, potentiates downstream effectors in the MAP kinase signaling pathway, and confers transforming properties in cell lines. ${ }^{12,15,16} B R A F^{V 600 E}$ has been detected in a variety of papillary thyroid neoplasms, including papillary microcarcinoma, and more recently, malignant struma ovarii, ${ }^{17-19}$ implying that the activating mutation is critical in the initiation of papillary thyroid neoplasia. The additional molecular changes that promote tumor progression, however, are not well characterized, but mutations in other oncogenes and tumor suppressor genes and altered cell signaling, cell cycle regulation, and apoptosis have been described in clinicopathologically aggressive thyroid neoplasms. ${ }^{16,18,20-22}$ As these changes have not been studied in the columnar cell variant of papillary thyroid carcinoma, we screened for mutations in $B R A F$ and evaluated the immunophenotypic expression of the neoplasia-associated biomarkers $\beta$-catenin, cyclin $\mathrm{D} 1$, the cell proliferation marker Ki-67 (MIB-1), bcl-2, p53, estrogen receptor (ER), and progesterone receptor (PR) in nine cases of clinically aggressive and indolent columnar cell carcinomas.

\section{Materials and methods}

Nine cases of columnar cell carcinoma from nine patients were identified from 5174 cases of papillary thyroid carcinoma diagnosed at three institutions (Brigham and Women's Hospital, Boston, MA, USA; Massachusetts General Hospital, Boston, MA, USA; and Mayo Clinic Rochester, Rochester, MN USA) between 1993 and 2005. These consisted of eight surgical and one autopsy specimens. The clinical history and pathology material were reviewed, and all cases fulfilled the current WHO classification criteria for the columnar cell variant of papillary thyroid carcinoma, including neoplastic cells with elongated nuclei, hyperchromasia, supranuclear and/or subnuclear cytoplasmic vacuolization, and papillary, follicular, trabecular, and/or solid growth patterns. ${ }^{23}$ The specimens were fixed in $10 \%$ neutral-buffered formalin, dehydrated, and embedded in paraffin resin. In all cases, routine and immunohistochemical stains for cyclin D1, MIB-1, $\beta$-catenin, bcl-2, p53, ER, and PR were performed
Table 1 Antibodies used

\begin{tabular}{lclcl}
\hline Antibody & Clone & \multicolumn{1}{c}{ Source } & Dilution & Pretreatment \\
\hline$\beta$-Catenin & 14 & BD Pharmigen & $1: 2000$ & Citrate PC \\
Bcl-2 & 124 & Dako & $1: 30$ & Citrate PC \\
Cyclin D1 & Dako & $1: 750$ & EDTA & \\
P53 & DO-1 & Immunotech & $1: 1200$ & Citrate PC \\
Estrogen receptor & SP1 & NeoMarker & $1: 100$ & Citrate PC \\
Progesterone & PgR636 & Dako & $1: 200$ & Citrate PC \\
receptor & mib1 & Dako & $1: 200$ & Citrate PC \\
MIB-1 & & & & \\
\hline
\end{tabular}

(Table 1). Polymerase chain reaction and direct forward and reverse sequencing of the $B R A F$ gene were performed on formalin-fixed paraffinembedded tissue as described previously. ${ }^{19,24,25}$

\section{Results}

The nine patients ranged in age from 32 to 90 years and consisted of five male patients (median age 60 years, mean 64.8 years) and four female patients (median age 37.5 years, mean 47 years). The clinical history, pathological assessment, treatment, and follow-up are detailed in Table 2. Pertinent past medical histories included chemotherapy and mantle irradiation for classical Hodgkin lymphoma in one patient, colorectal carcinoma in one patient, and remote partial thyroidectomy for a goiter in one patient. The nine tumors were resected in eight patients and incidentally discovered in one patient during a post-mortem examination. The surgical procedures included lobectomy followed by completion thyroidectomy in two patients, and total thyroidectomy in six patients, including one with a concomitant laryngotracheal resection (patient 7). Resection of the tumor was followed by postoperative radioactive iodine in seven, radiotherapy in three, and adjuvant chemotherapy with adriamycin in one (patient 7). Clinical follow-up ranged from 3 to 59 months and was available for all patients. One patient with an incidental thyroid carcinoma discovered at autopsy died of disseminated diffuse large B-cell lymphoma (patient 4).

All tumors except one were solitary; a $0.4 \mathrm{~cm}$ intrathyroidal metastatic focus was identified in case 7. Chronic lymphocytic thyroiditis was present in two cases, and coexisting minimally invasive follicular carcinoma and papillary microcarcinoma were present in one case (case 3). Four tumors were clinically indolent (cases 1-4) and five were aggressive (cases 5-9). Patients with indolent tumors included one male patient and three female patients (age 32-90 years, median 38, mean 49), all of whom had an asymptomatic or painless mass that was encapsulated or well circumscribed $(1.3-4.0 \mathrm{~cm}$, mean $2.1 \mathrm{~cm}$; Figure 1a). Two of the tumors exhibited minimal invasion through the capsule, but none had extrathyroidal extension; all were low 
Table 2 Clinical features

\begin{tabular}{|c|c|c|c|c|c|c|c|}
\hline Case & $\begin{array}{c}\text { Age } \\
\text { (years) }\end{array}$ & Gender & Clinical history & Treatment & Clinical outcome & $\begin{array}{l}\text { Length of } \\
\text { follow-up }\end{array}$ & Extent of invasion and metastasis \\
\hline 1 & 32 & $\mathrm{~F}$ & $\begin{array}{l}\text { Asymptomatic, non-functional } \\
\text { thyroid mass }\end{array}$ & $\begin{array}{l}\text { Total thyroidectomy and } \\
\text { radioactive iodine }\end{array}$ & $\begin{array}{l}\text { Alive with no evidence } \\
\text { of disease }\end{array}$ & 5 years & $\begin{array}{l}\text { Encapsulated carcinoma with minimal } \\
\text { invasion. No extrathyroidal extension }\end{array}$ \\
\hline 2 & 35 & $\mathrm{~F}$ & Asymptomatic thyroid mass & $\begin{array}{l}\text { Total thyroidectomy and } \\
\text { radioactive iodine }\end{array}$ & $\begin{array}{l}\text { Alive with no evidence } \\
\text { of disease }\end{array}$ & $\begin{array}{l}4 \text { years } \\
11 \text { months }\end{array}$ & $\begin{array}{l}\text { Encapsulated carcinoma with minimal } \\
\text { invasion. No extrathyroidal extension }\end{array}$ \\
\hline 3 & 40 & $\mathrm{~F}$ & $\begin{array}{l}\text { Painless neck mass. Distant history } \\
\text { of classical Hodgkin lymphoma treated } \\
\text { with chemotherapy and radiotherapy }\end{array}$ & $\begin{array}{l}\text { Total thyroidectomy and } \\
\text { radioactive iodine }\end{array}$ & $\begin{array}{l}\text { Alive with no evidence } \\
\text { of disease }\end{array}$ & $\begin{array}{l}1 \text { year } \\
11 \text { months }\end{array}$ & $\begin{array}{l}\text { Well-circumscribed carcinoma. } \\
\text { No extrathyroidal extension. Concurrent } \\
1.5 \mathrm{~cm} \text { minimally invasive follicular } \\
\text { carcinoma and microcarcinoma }\end{array}$ \\
\hline 4 & 90 & $\mathrm{M}$ & $\begin{array}{l}\text { Subclinical thyroid mass. Nodal and } \\
\text { retroperitoneal diffuse large B-cell } \\
\text { lymphoma. Incidental gastric } \\
\text { gastrointestinal stromal tumor }(0.8 \mathrm{~cm})\end{array}$ & None & Post mortem & $\begin{array}{l}\text { None } \\
\text { (post } \\
\text { mortem) }\end{array}$ & $\begin{array}{l}\text { Well-circumscribed, non-encapsulated } \\
\text { carcinoma. No extrathyroidal extension }\end{array}$ \\
\hline 5 & 45 & M & Thyroid mass & $\begin{array}{l}\text { Thyroidectomy, radioactive } \\
\text { iodine, radiotherapy, and } \\
\text { gamma knife surgery for } \\
\text { brain metastasis }\end{array}$ & Died of disease & $\begin{array}{l}3 \text { years } \\
9 \text { months }\end{array}$ & $\begin{array}{l}\text { Poorly circumscribed carcinoma with } \\
\text { metastasis to cervical lymph nodes, } \\
\text { distal femur, brain, and spinal cord }\end{array}$ \\
\hline 6 & 51 & M & Thyroid mass & $\begin{array}{l}\text { Thyroidectomy, radioactive } \\
\text { iodine, and radiotherapy }\end{array}$ & $\begin{array}{l}\text { Died of disease (metastasis } \\
\text { to liver, right humerus, } \\
\text { and spinal cord) }\end{array}$ & $\begin{array}{l}1 \text { year } \\
5 \text { months }\end{array}$ & Poorly circumscribed carcinoma \\
\hline 7 & 60 & M & Thyroid and neck mass & $\begin{array}{l}\text { Total thyroidectomy, } \\
\text { laryngotracheal resection, } \\
\text { radioactive iodine, and } \\
\text { adriamycin chemotherapy }\end{array}$ & $\begin{array}{l}\text { Died of disease (recurrence } \\
\text { in left neck, and metastasis } \\
\text { to lung and spinal cord) }\end{array}$ & $\begin{array}{l}3 \text { years } \\
4 \text { months }\end{array}$ & $\begin{array}{l}\text { Poorly circumscribed carcinoma with } \\
\text { invasion of trachea and metastasis } \\
\text { to cervical and mediastinal lymph nodes }\end{array}$ \\
\hline 8 & 78 & M & $\begin{array}{l}\text { Symptomatic thyroid mass with } \\
\text { shortness of breath, hoarseness, stridor, } \\
\text { hemoptysis, and cervical } \\
\text { lymphadenopathy. History of smoking } \\
\text { and colon cancer }\end{array}$ & $\begin{array}{l}\text { Total thyroidectomy } \\
\text { (refused laryngectomy) } \\
\text { and radiotherapy } \\
\text { to residual tumor in } \\
\text { surgical bed }\end{array}$ & $\begin{array}{l}\text { Alive with disease } \\
\text { (local recurrence and } \\
\text { metastasis to lung) }\end{array}$ & $\begin{array}{l}2 \text { years } \\
1 \text { month }\end{array}$ & $\begin{array}{l}\text { Poorly circumscribed carcinoma with } \\
\text { extrathyroidal extension and } \\
\text { laryngotracheal invasion }\end{array}$ \\
\hline 9 & 81 & $\mathrm{~F}$ & $\begin{array}{l}\text { Symptomatic thyroid mass with tracheal } \\
\text { deviation and dysphagia. Distant history } \\
\text { of partial thyroidectomy for goiter }\end{array}$ & $\begin{array}{l}\text { Completion thyroidectomy } \\
\text { and radioactive iodine }\end{array}$ & $\begin{array}{l}\text { Alive with no evidence } \\
\text { of disease }\end{array}$ & 3 months & $\begin{array}{l}\text { Poorly circumscribed carcinoma with } \\
\text { extrathyroidal extension and } \\
\text { involvement of radial margins }\end{array}$ \\
\hline
\end{tabular}



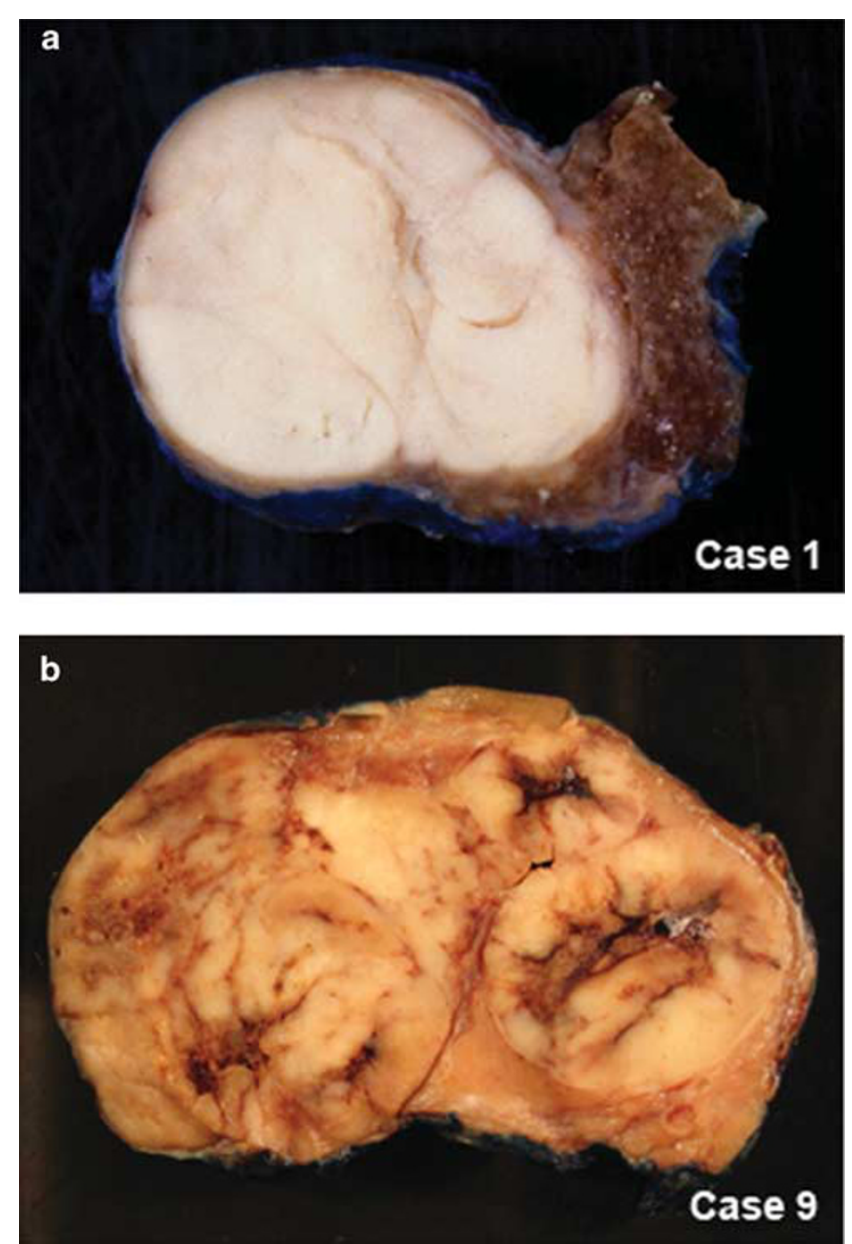

Figure 1 Gross pathological features of columnar cell variant of papillary thyroid carcinoma: (a) Well-circumscribed and partially encapsulated tumor, case 1; and (b) large tumor, diffusely infiltrative, case 9.

in tumor stage (AJCC, stage I or II). ${ }^{26}$ All patients who underwent resection of the tumor were alive and without evidence of residual disease for 59 months following diagnosis and treatment; however, some patients do not have adequate follow-up to correctly assess the aggressiveness of these circumscribed tumors (Table 2).

Five patients with aggressive disease (four males and one female, age 45-81 years, median 60, mean 63) presented with clinically worrisome features that included progressive shortness of breath, hoarseness, stridor, tracheal deviation, dysphagia, and metastasis. The tumors were large $(4.0-11.5 \mathrm{~cm}$, mean $6.7 \mathrm{~cm}$; Figure 1b) and diffusely infiltrative with extrathyroidal extension, laryngotracheal invasion, and/or cervical lymph nodal or distant metastasis (AJCC, stage III or IV). ${ }^{26}$ Three died of widely metastatic disease 17-45 months after the initial diagnosis. One was alive with residual tumor in the surgical bed as well as a metastatic focus in the lung at 25 months follow-up (patient 8), whereas another had tumor at the surgical margin, but was alive and without disease following a short follow-up interval (patient 9) (Table 2).

The histological, architectural, and cytological features fulfilled the diagnostic criteria of the columnar cell variant of papillary thyroid carcinoma as defined by the current WHO classification, including neoplastic follicular cells with basally pseudostratified, hyperchromatic nuclei with eosinophilic-to-clear cytoplasm and supranuclear and/ or subnuclear cytoplasmic vacuoles that resembled secretory-type endometrium (Figure 2, Table 3). ${ }^{23} \mathrm{In}$ some instances, focal areas of chromatin clearing typical of conventional papillary carcinoma were identified. The cells were arranged in a variety of architectural patterns that included papillary, follicular, trabecular, cribriform, complex glandular, and/or solid. In one case, keratinizing squamous differentiation including squamous morules was present (case 3). Among the clinically aggressive tumors, focal solid and insular patterns were identified in two cases (cases 8 and 9) and necrosis in two cases (cases 7 and 9). Mitoses ranged from rare to up to 18 per 10 high-power fields. Colloid and dystrophic and psammomatous calcification were present in the majority of cases.

$B R A F^{V 600 E}$ was identified in three of nine cases (cases 4, 7, and 8; Figure 3); no additional mutation in $B R A F$ was detected. The three tumors were from male patients who were 60,78 , and 90 years of age at the time of diagnosis and included one clinically indolent and two aggressive carcinomas. Of the aggressive neoplasms, one exhibited extrathyroidal extension with laryngeal and tracheal invasion and lung metastasis, whereas the other recurred with lung and spinal metastasis following surgical excision and adjuvant radio- and chemotherapy. The indolent columnar cell carcinoma was an incidental tumor discovered at autopsy.

Immunohistochemical studies of a variety of neoplasia-associated biomarkers were performed on paraffin-embedded tissue (Figure 4, Table 3). In virtually all cases, nuclear cyclin D1 was detected in the majority of neoplastic cells, although the staining intensity was variable from cell to cell and ranged from weak to strong. An increased Ki-67 cell proliferation index, measured by nuclear staining with the monoclonal antibody, MIB-1, was observed in both indolent and aggressive neoplasms with indices ranging from $<5 \%$ to approximately $30 \%$. The expression of $\beta$-catenin was detected in a membranous pattern in seven of nine cases, of which the staining intensity was strong in five and weak in two. Coexisting membranous and cytoplasmic expression was present in two cases (cases 4 and 7), and cytoplasmic and membranous staining expression in another two (cases 2 and 3). Bcl-2 expression was variable, but was overall mildly decreased in indolent tumors. Immunoreactivity for p53 was detected, but weak in seven of nine cases. There was nuclear expression of the hormone receptor, ER, in six cases, including three indolent 

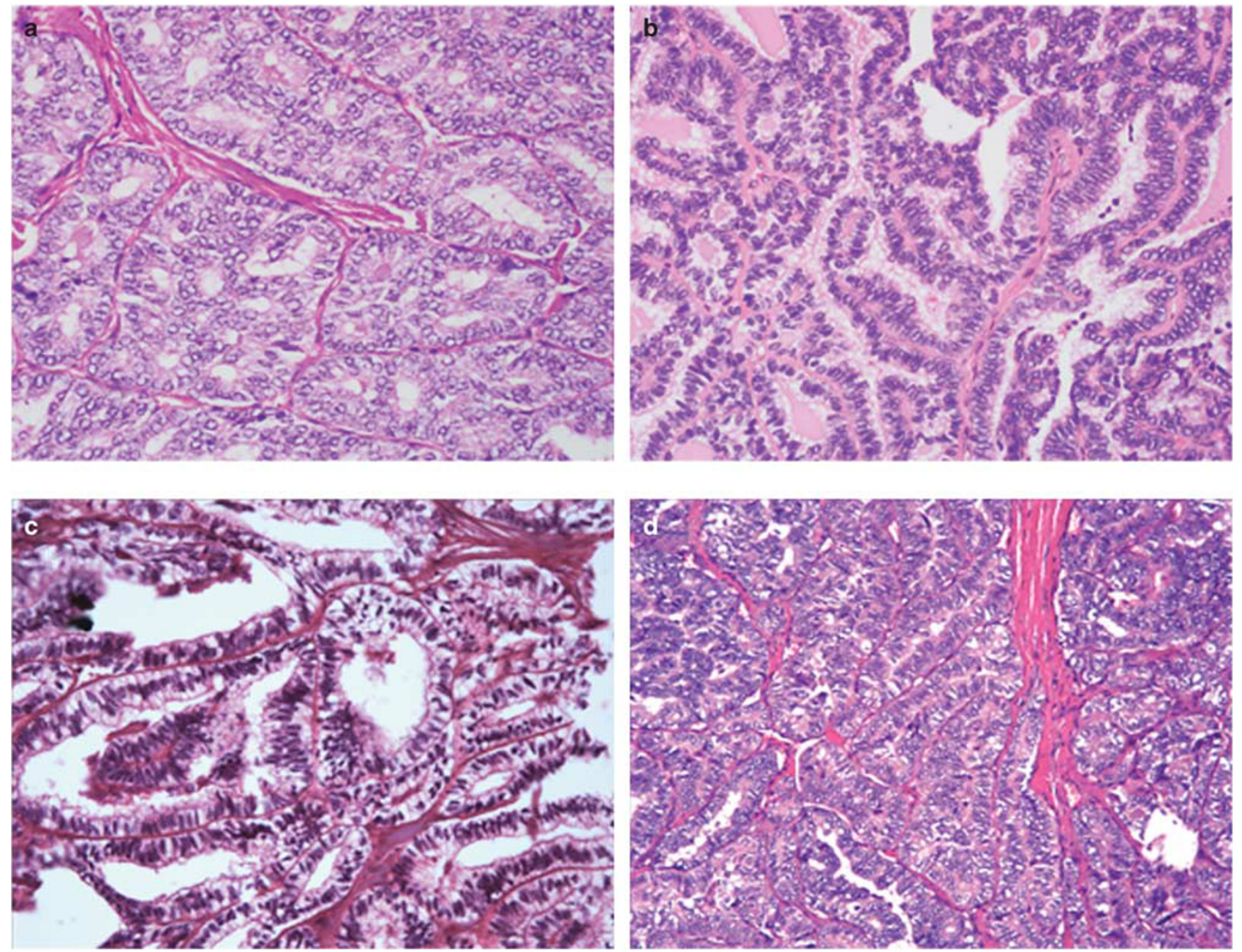

Figure 2 The histopathological, architectural, and cytological features diagnostic of the columnar cell variant of papillary thyroid carcinoma: neoplastic follicular cells with pseudostratified, hyperchromatic nuclei with eosinophilic-to-clear cytoplasm, and supranuclear and/or subnuclear cytoplasmic vacuoles that resembled secretory-type endometrium. The cells were arranged in papillary, follicular, trabecular, cribriform, complex glandular, and/or solid architectural patterns (a, case 5; b, case 6; c, case 7; and d, case 8).

and three aggressive tumors from three female and three male patients. Nuclear staining for PR was detected in five tumors from three female and two male patients. The adjacent non-neoplastic thyroid follicular tissue, by comparison, showed negativeto-focally weak nuclear staining for cyclin D1, labeling of rare follicular cells by MIB-1, strong membranous expression of $\beta$-catenin, strong cytoplasmic staining for bcl-2, negative-to-focal and weak reactivity for $\mathrm{p53}$, no detectable nuclear reactivity for ER, and negative-to-focal nuclear reactivity for $P R$.

\section{Discussion}

Papillary thyroid carcinomas encompass a clinicopathological spectrum of neoplasms with different biological behavior. The vast majority is indolent and associated with long-term survival. A small subset of these tumors, however, may progress to more aggressive neoplasms such as poorly differentiated and undifferentiated carcinomas. ${ }^{11,27}$ Mutations of candidate genes such as TP53 and CTNNB1, the gene encoding $\beta$-catenin, and abnormal cell cycle regulation, proliferation, and apoptosis are associated with aggressive neoplasms and have been suggested as markers of thyroid tumor progression. ${ }^{28-32}$

Columnar cell carcinoma is a recognized variant of well-differentiated papillary thyroid carcinoma that is associated with an uncertain clinical course. Small size, encapsulation, and tumor circumscription are associated with a more favorable prognosis, whereas large size, extrathyroidal extension, and metastasis confer a worse prognosis. Because previous studies of these neoplasms have been largely limited to case studies, we reviewed reports in the English literature to date to better define the clinicopathological characteristics of these rare neoplasms. ${ }^{1-9,33-48}$

The 48 reported cases consisted of 15 men and 33 women. Men ranged in age from 29 to 77 years 
Table 3 Pathological and immunophenotypical features and $B R A F$ gene status

\begin{tabular}{|c|c|c|c|c|c|c|c|c|c|c|c|}
\hline Case & Histopathology & $\begin{array}{l}\text { Size of } \\
\text { tumor } \\
(\mathrm{cm})\end{array}$ & $\begin{array}{l}\text { Pathological } \\
\text { stage } \\
(\text { AJCC, 2010) }\end{array}$ & BRAF & Cyclin D1 & $K i-67(\%)$ & $\beta$-Catenin & Bcl-2 & P53 & $E R$ & $P R$ \\
\hline 1 & $\begin{array}{l}\text { Pseudostratified columnar } \\
\text { cells in predominantly } \\
\text { cribriform and focal } \\
\text { trabecular patterns }\end{array}$ & 4.0 & pT2 Nx & $\begin{array}{l}\text { Wild- } \\
\text { type }\end{array}$ & $\begin{array}{l}\text { Subset } \\
\text { positive } \\
(20 \%)\end{array}$ & 10 & $\begin{array}{l}\text { Membranous } \\
\text { (strong) }\end{array}$ & Positive & $\begin{array}{l}\text { Weak, } \\
\text { subset }\end{array}$ & Positive & Positive \\
\hline 2 & $\begin{array}{l}\text { Pseudostratified columnar } \\
\text { cells in papillary pattern }\end{array}$ & 1.5 & pT1b Nx & $\begin{array}{l}\text { Wild } \\
\text { type }\end{array}$ & Positive & $<5$ & Cytoplasmic & Positive & $\begin{array}{l}\text { Weak, } \\
\text { subset }\end{array}$ & Positive & Positive \\
\hline 3 & $\begin{array}{l}\text { Pseudostratified columnar } \\
\text { cells in papillary and focal } \\
\text { solid patterns intermixed } \\
\text { with keratinizing squamous } \\
\text { morules }\end{array}$ & 1.5 & pT1b Nx & $\begin{array}{l}\text { Wild } \\
\text { type }\end{array}$ & Positive & 30 & Cytoplasmic & $\begin{array}{l}\text { Weak, } \\
\text { focally } \\
\text { positive }\end{array}$ & Weak & Positive & $\begin{array}{l}\text { Positive } \\
\text { (subset) }\end{array}$ \\
\hline 4 & $\begin{array}{l}\text { Columnar cells, focally } \\
\text { pseudostratified in follicular } \\
\text { and trabecular patterns }\end{array}$ & 1.3 & pT1b No M0 & $\begin{array}{l}\text { T1799A } \\
\text { (V600E) }\end{array}$ & Positive & 5 & $\begin{array}{l}\text { Membranous } \\
\text { (strong) and } \\
\text { cytoplasmic }\end{array}$ & $\begin{array}{l}\text { Weak, } \\
\text { focally } \\
\text { positive }\end{array}$ & Weak, subset & Negative & Negative \\
\hline 5 & $\begin{array}{l}\text { Pseudostratified columnar } \\
\text { cells in papillary, trabecular, } \\
\text { and complex glandular } \\
\text { patterns }\end{array}$ & 7.5 & pT3 N1b M1 & $\begin{array}{l}\text { Wild } \\
\text { type }\end{array}$ & Positive & $<5$ & $\begin{array}{l}\text { Membranous } \\
\text { (weak) }\end{array}$ & $\begin{array}{l}\text { Weak, } \\
\text { focally } \\
\text { positive }\end{array}$ & Negative & Negative & Negative \\
\hline 6 & $\begin{array}{l}\text { Pseudostratified columnar } \\
\text { cells in a complex } \\
\text { glandular pattern }\end{array}$ & 6.0 & pT3 No & $\begin{array}{l}\text { Wild } \\
\text { type }\end{array}$ & Positive & $<5 \%$ & $\begin{array}{l}\text { Membranous } \\
\text { (weak) }\end{array}$ & Positive & Negative & Positive & $\begin{array}{l}\text { Focally } \\
\text { positive }\end{array}$ \\
\hline 7 & $\begin{array}{l}\text { Pseudostratified columnar } \\
\text { cells in papillary, follicular, } \\
\text { and focally trabecular } \\
\text { patterns with tumor } \\
\text { necrosis }\end{array}$ & 6.0 & pT4a N1b & $\begin{array}{l}\text { T1799A } \\
\text { (V600E) }\end{array}$ & Positive & 10 & $\begin{array}{l}\text { Membranous } \\
\text { (strong) and } \\
\text { cytoplasmic }\end{array}$ & Positive & $\begin{array}{l}\text { Weak, } \\
\text { focal }\end{array}$ & Positive & Negative \\
\hline 8 & $\begin{array}{l}\text { Pseudostratified columnar } \\
\text { cells in papillary, } \\
\text { micropapillary, follicular, } \\
\text { and complex glandular } \\
\text { patterns with solid features }\end{array}$ & 4.0 & pT4a Nx & $\begin{array}{l}\text { T1799A } \\
\text { (V600E) }\end{array}$ & Positive & 15 & $\begin{array}{l}\text { Membranous } \\
\text { (strong) }\end{array}$ & Positive & $\begin{array}{l}\text { Weakly } \\
\text { positive }\end{array}$ & Positive & $\begin{array}{l}\text { Focally } \\
\text { positive }\end{array}$ \\
\hline 9 & $\begin{array}{l}\text { Columnar cells in trabecular, } \\
\text { microfollicular, complex } \\
\text { glandular, and solid patterns } \\
\text { with focal necrosis }\end{array}$ & 11.5 & pT3 No & $\begin{array}{l}\text { Wild } \\
\text { type }\end{array}$ & Positive & 10 & $\begin{array}{l}\text { Membranous } \\
\text { (strong) }\end{array}$ & Positive & Weak & Negative & Negative \\
\hline
\end{tabular}

(mean 49.5 years, median 47 years) and women from 16 to 83 years (mean 49 years, median 50 years). Of these cases, 20 clinically indolent (two men and 18 women, mean 44.9 years, median 41.5 years) and 23 aggressive (13 men and 10 women, mean 55.6 years, median 59.5 years) neoplasms were characterized. Indolent tumors ranged in size from 0.9 to $8 \mathrm{~cm}$ (mean $3.6 \mathrm{~cm}$, median $3.8 \mathrm{~cm}$ ), and aggressive tumors ranged from 0.6 to $10 \mathrm{~cm}$ (mean $6.0 \mathrm{~cm}$, median $6.3 \mathrm{~cm}$ ). Of cases with clinical follow-up, 18 of 19 patients with indolent tumors were alive and/or without disease ranging from 9 months to 22 years after the diagnosis (mean 67 months, median 48 months). Of 20 patients with aggressively behaving carcinomas, 13 died of disease ranging from 7 to 126 months after the diagnosis (mean 41.9 months, median 36 months); five patients were alive, but with disease ranging from 16 to 108 months followup (Table 4).

Similarly, by comparison, the four indolent neoplasms studied herein were small (mean $2.1 \mathrm{~cm}$ ), encapsulated, or well-circumscribed, affected younger (median 38 years), predominantly female patients, did not recur following definitive surgical management and adjuvant therapy, and/or was incidentally discovered at post mortem. By contrast, the five clinically aggressive neoplasms were large (mean $6.7 \mathrm{~cm}$ ), diffusely infiltrative with extrathyroidal extension and metastasis to regional lymph nodes and distant visceral sites, affected older (median 60 years), predominantly male patients, and associated with early death and/or recurrence of disease in four of five patients.

$B R A F^{V 600 E}$ was detected in three of nine $(33 \%)$ columnar cell carcinomas, a finding that is comparable to its overall prevalence in well-differentiated papillary thyroid carcinomas and provides the genetic basis for columnar cell carcinoma as a distinct variant of papillary thyroid carcinoma. ${ }^{49,50}$ Interestingly, $B R A F^{V 600 E}$ was limited to tumors in older male patients, a population more prone to harbor an aggressive papillary neoplasm. ${ }^{22}$ Early work suggested that altered $B R A F$ is an adverse prognostic variable due to its association with unfavorable clinicopathological characteristics such as older age, male gender, and distant metastasis, and the high prevalence of BRAF mutations in the clinically aggressive tall-cell variant of papillary 
a

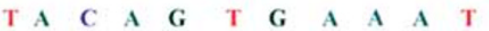

b

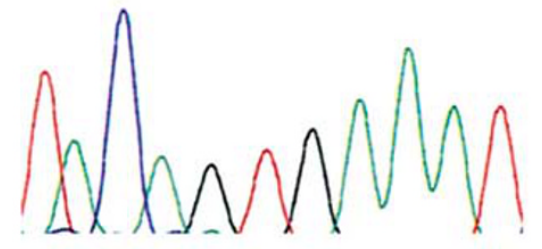

c $\downarrow$

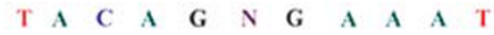

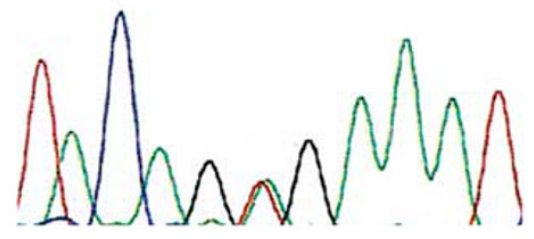

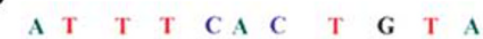

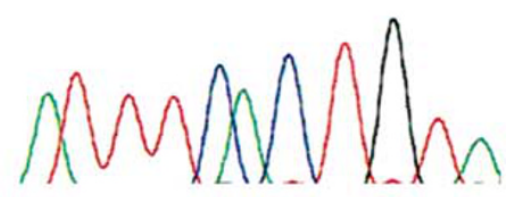

d

$\downarrow$

$\begin{array}{llllllllllll}A & T & T & T & C & T & C & T & G & T & A\end{array}$

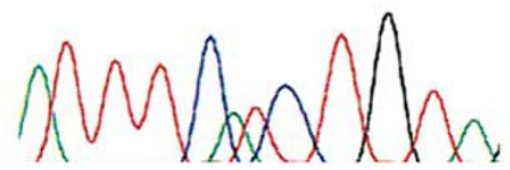

Figure 3 Bi-directional sequencing of $B R A F$ in columnar cell variant of papillary thyroid carcinoma. Case 3 shows wild-type sequence in forward (a) and reverse (b) directions. Case 8 shows a T to A transversion at nucleotide $1799\left(B R A F^{V 60 o E}\right)$ in forward (c) and reverse (d) directions (arrows).
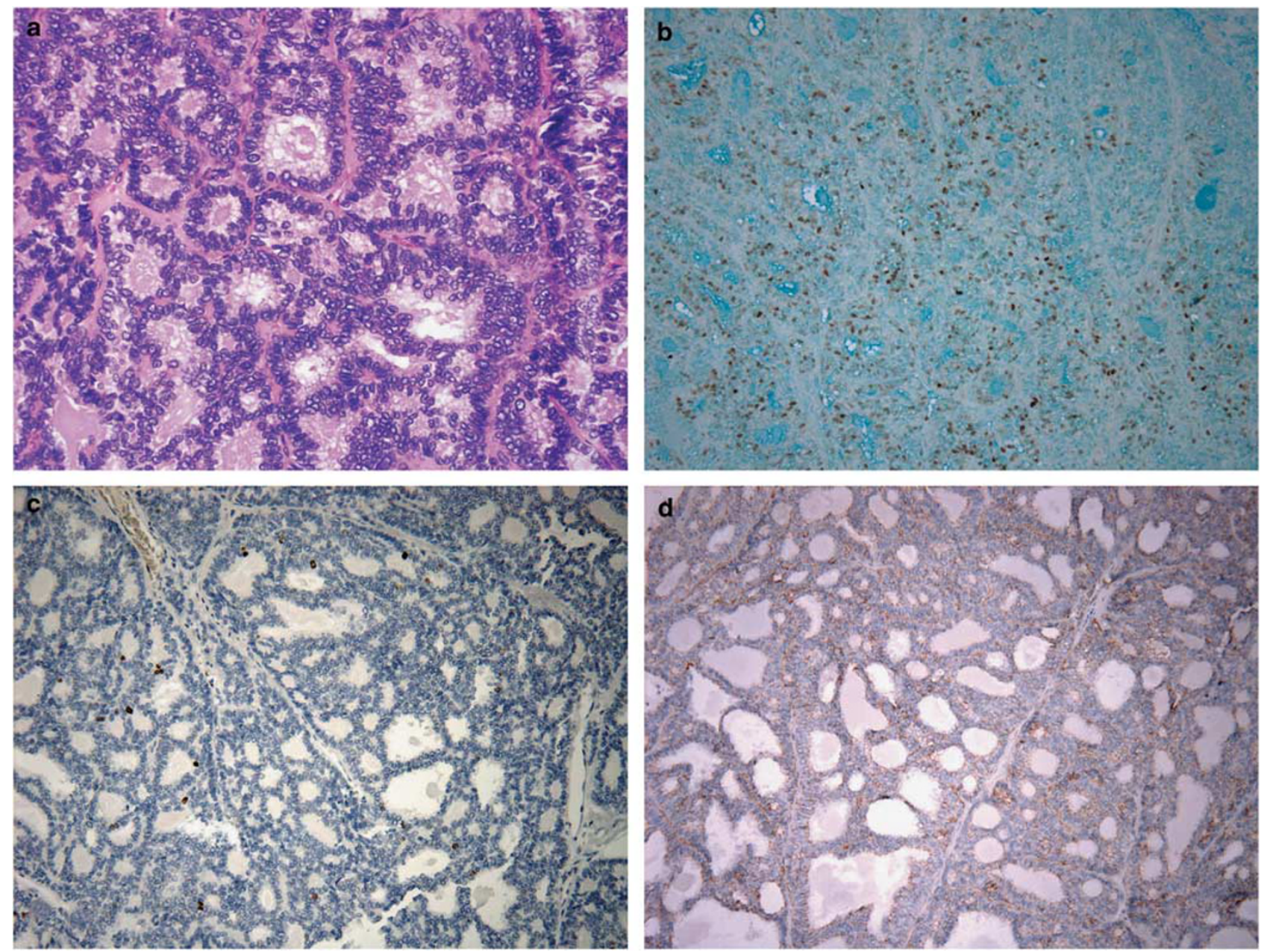

Figure 4 Morphological characteristics: (a) hematoxylin and eosin (case 6); immunohistochemical features of columnar cell variant of papillary thyroid carcinoma; (b) cyclin D1, (c) Ki-67, (d) $\beta$-catenin, (e) bcl-2, (f) p53, (g) ER, and (h) PR (case 6). 

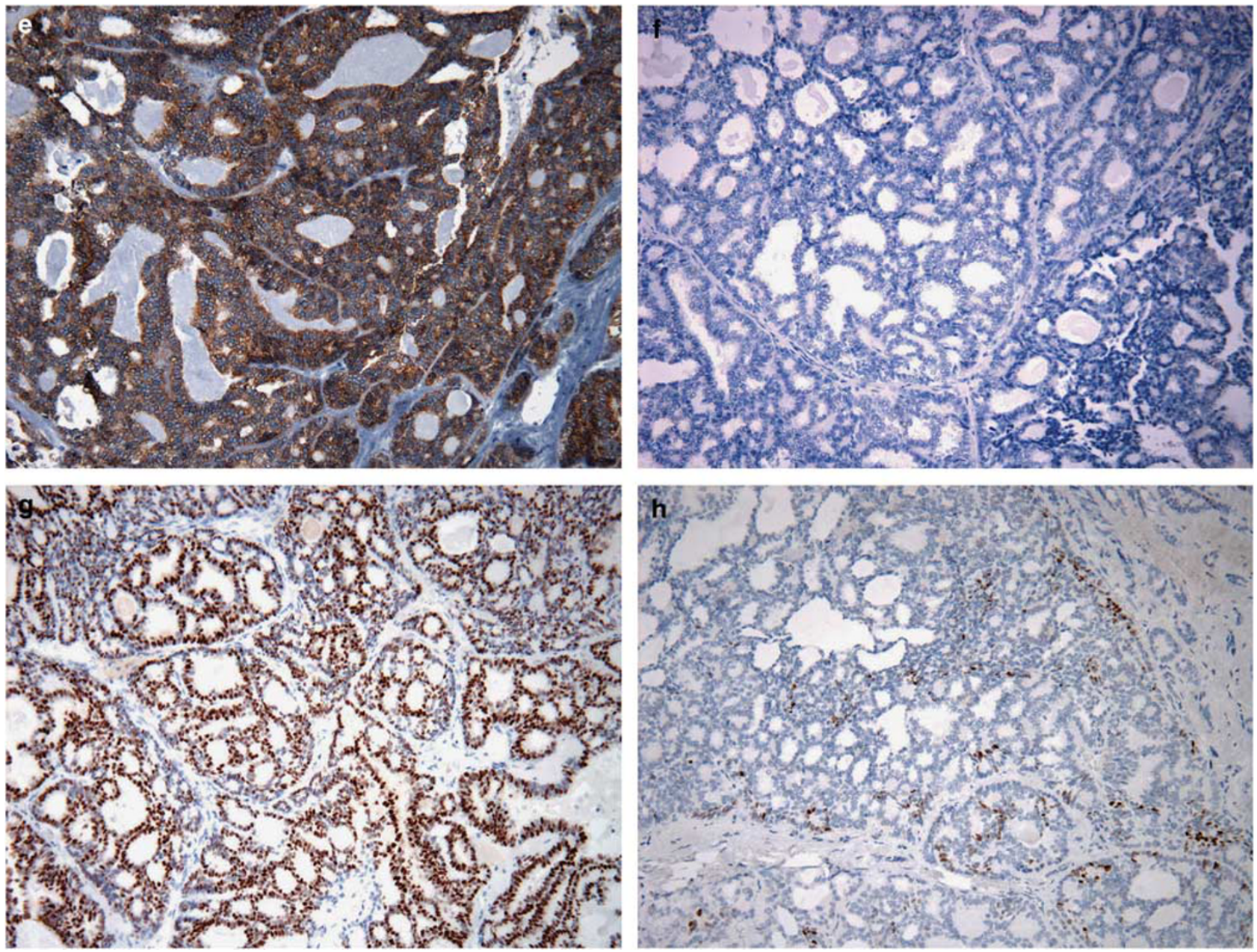

Figure 4 Continued.

Table 4 Number of reported cases (48)

\begin{tabular}{llc}
\hline & Number & $\begin{array}{c}\text { Mean age } \\
\text { (years) }\end{array}$ \\
\hline Gender & & \\
Male & 15 & 49.5 \\
Female & 33 & 49 \\
& & \\
Cases of clinically indolent & neoplasms (20) & \\
Gender & Male 2, female 18 & \\
Age (mean) & 44.9 & \\
Tumor size (mean) & $3.6 \mathrm{~cm}$ & \\
Outcome (mean & $18 / 19$ alive & \\
follow-up, 67 months) & and/or without disease & \\
& & \\
Cases of clinically aggressive neoplasms (23) & Male 13, female 10 \\
Gender & 55.6 \\
Age (mean) & $6.0 \mathrm{~cm}$ \\
Tumor size (mean) & $13 / 20$ died of disease \\
Outcome (mean & $5 / 20$ alive with disease \\
follow-up, 41.9 months) & \\
\hline
\end{tabular}

carcinoma and poorly differentiated and undifferentiated carcinomas. ${ }^{16,18,21,22,49,51,52}$ However, $B R A F^{V 6 O O E}$ is also found in papillary thyroid micro- carcinoma, a tumor that is typically benign and often discovered as an incidental finding, as well as in pre-malignant colorectal and nevocellular lesions, suggesting that an activating mutation in $B R A F$ occurs early in the initiation of papillary thyroid neoplasia and may additionally confer susceptibility for malignant progression. ${ }^{12,17,18,53-56}$ Compatible with this interpretation, one of the three tumors harboring $B R A F^{V 600 E}$ in this study was clinically indolent, whereas two behaved aggressively.

Cyclin D1, the gene product of CCND1, is an inducible promoter of cell cycle progression that is abnormally upregulated in a variety of benign and malignant neoplasms. ${ }^{57,58} \mathrm{~A}$ positive correlation between the nuclear overexpression of cyclin D1, cellular proliferation, and the proliferation marker, Ki-67, with tumor stage and aggressive biological behavior was reported previously. ${ }^{31,32,39,59-64}$ An alteration in the gene encoding cyclin D1 has not been reported in thyroid neoplasia, but a link between aberrant $\beta$-catenin expression and upregulation of cyclin D1 has been shown in a variety of neoplasms. ${ }^{65-67}$ 
In this study, the nuclear expression of cyclin D1 was markedly increased in the vast majority of indolent and aggressive neoplasms. This finding contrasts with conventional papillary thyroid carcinomas in which cyclin D1 is only expressed in a low percentage of neoplastic cells. The level and pattern of $\beta$-catenin expression were variable in both indolent and aggressive tumors and included strong and weak membranous, cytoplasmic, or both patterns; aberrant nuclear localization of $\beta$-catenin was not seen. Previous reports have documented an elevated mitotic index of 2-13 per $10 \mathrm{HPF}$ and a Ki67 labeling index of approximately $20 \%$ in aggressively behaving columnar cell carcinomas. ${ }^{3,6,34,36,47}$ In this study, the overall Ki-67 index in columnar cell carcinoma was greater than that previously reported in conventional papillary thyroid carcinomas. ${ }^{59,68}$ However, Ki-67 labeling of neoplasms presenting at low and high tumor staging was widely variable and overlapping; indolent tumors exhibited Ki-67 proliferation indices of up to $30 \%$, whereas an aggressive tumor displayed a Ki-67 index of less than $5 \%$. No discernible correlation between cyclin D1, $\beta$-catenin, and Ki-67 labeling index was identified, suggesting that factors other than cell cycle regulation and signaling may promote further malignant growth. In addition, the oncogenic role of cyclin D1 as a transcriptional modulator, independent of promoting cell cycle progression, warrants further evaluation. ${ }^{66,69}$

Defective p53, the tumor suppressor gene product, and altered regulation of apoptosis are typically regarded as markers of progressed tumors. When mutated, defective p53 fails to block cell cycle progression and induce apoptosis in cells with DNA damage, leading to further genomic instability. In thyroid neoplasms, defective p53 and loss of expression of the antiapoptotic protein, bcl-2, are more common in poorly differentiated and undifferentiated carcinomas than well-differentiated neoplasms. ${ }^{70-75}$ In this study, nuclear p53 immunoreactivity was weak in three of five aggressive tumors as well as in all indolent tumors, likely reflecting an intact p53 expression. Interestingly, bcl-2 expression was diminished in the majority of indolent tumors, whereas a strong, cytoplasmic staining was seen in the majority of aggressive tumors.

Thyroid tumors show gender- and age-specific differences in prevalence, behavior, and outcome. Papillary carcinomas have an overall higher prevalence, but better prognosis in women of childbearing age, suggesting that sex hormones may influence tumor initiation and growth. ${ }^{76,77}$ Similar to previous studies of papillary thyroid carcinoma ${ }^{78-81}$ expression of ER and PR was increased in the majority of columnar cell carcinomas, but was without discernible gender- or age-specific differences in expression. However, whereas ER expression was detected in the majority of both indolent and aggressive tumors, PR expression was diffusely positive in the majority (three of four) of indolent tumors, but only focally positive in two of five aggressive tumors, implying a possible role for diminished or absent PR expression as a marker for clinicopathologically aggressive columnar cell carcinoma.

As previously described in the literature and further supported by this study, the columnar cell variant of papillary thyroid carcinoma can be separated into circumscribed and widely invasive subtypes corresponding to the clinicopathological indolent and aggressive carcinomas. The morphology of columnar cell variant is often reminiscent of endometrial or colonic carcinoma, with some of the nuclear features of papillary thyroid carcinoma. Our study reveals $B R A F^{V 600 E}$ to be detected in $33 \%$ of our cases, a comparable finding to its overall prevalence in well-differentiated papillary thyroid carcinomas and provides the genetic basis for columnar cell carcinoma as a distinct variant of papillary thyroid carcinoma. Ancillary molecular and immunophenotypic studies may also aid in this distinction.

\section{Acknowledgement}

We thank Dr G Pinkus for expert assistance with the immunohistochemical preparation.

\section{Disclosure/conflict of interest}

The authors have no financial and commercial interests to disclose.

\section{References}

1 Akslen LA, Varhaug JE. Thyroid carcinoma with mixed tall-cell and columnar-cell features. Am J Clin Pathol 1990;94:442-445.

2 Evans HL. Columnar-cell carcinoma of the thyroid. a report of two cases of an aggressive variant of thyroid carcinoma. Am J Clin Pathol 1986;85:77-80.

3 Berends D, Mouthaan PJ. Columnar-cell carcinoma of the thyroid. Histopathology 1992;20:360-362.

4 Gaertner EM, Davidson M, Wenig BM. The columnar cell variant of thyroid papillary carcinoma. case report and discussion of an unusually aggressive thyroid papillary carcinoma. Am J Surg Pathol 1995;19: 940-947.

5 Mizukami Y, Nonomura A, Michigishi T, et al. Columnar cell carcinoma of the thyroid gland: a case report and review of the literature. Hum Pathol 1994;25:1098-1101.

6 Sobrinho-Simoes M, Nesland JM, Johannessen JV. Columnar-cell carcinoma. another variant of poorly differentiated carcinoma of the thyroid. Am J Clin Pathol 1988;89:264-267.

7 Evans HL. Encapsulated columnar-cell neoplasms of the thyroid. a report of four cases suggesting a favorable prognosis. Am J Surg Pathol 1996;20:1205-1211.

8 Ferreiro JA, Hay ID, Lloyd RV. Columnar cell carcinoma of the thyroid: report of three additional cases. Hum Pathol 1996;27:1156-1160. 
9 Wenig BM, Thompson LD, Adair CF, et al. Thyroid papillary carcinoma of columnar cell type: a clinicopathologic study of 16 cases. Cancer 1998;82:740-753.

10 Kondo T, Ezzat S, Asa SL. Pathogenetic mechanisms in thyroid follicular-cell neoplasia. Nat Rev Cancer 2006;6:292-306.

11 Delellis RA. Pathology and genetics of thyroid carcinoma. J Surg Oncol 2006;94:662-669.

12 Davies H, Bignell GR, Cox C, et al. Mutations of the braf gene in human cancer. Nature 2002;417:949-954.

13 Kimura ET, Nikiforova MN, Zhu Z, et al. High prevalence of braf mutations in thyroid cancer: genetic evidence for constitutive activation of the Ret/Ptc-RasBraf signaling pathway in papillary thyroid carcinoma. Cancer Res 2003;63:1454-1457.

14 Xing M. Braf mutation in papillary thyroid cancer: pathogenic role, molecular bases, and clinical implications. Endocr Rev 2007;28:742-762.

15 Wan PT, Garnett MJ, Roe SM, et al. Mechanism of activation of the Raf-Erk signaling pathway by oncogenic mutations of B-Raf. Cell 2004;116:855-867.

16 Namba H, Nakashima M, Hayashi T, et al. Clinical implication of hot spot braf mutation, V599e, in papillary thyroid cancers. J Clin Endocrinol Metab 2003;88:4393-4397.

17 Sedliarou I, Saenko V, Lantsov D, et al. The Braf T1796a transversion is a prevalent mutational event in human thyroid microcarcinoma. Int J Oncol 2004;25: 1729-1735.

18 Nikiforova MN, Kimura ET, Gandhi M, et al. Braf mutations in thyroid tumors are restricted to papillary carcinomas and anaplastic or poorly differentiated carcinomas arising from papillary carcinomas. J Clin Endocrinol Metab 2003;88:5399-5404.

19 Schmidt J, Derr V, Heinrich MC, et al. Braf in papillary thyroid carcinoma of ovary (Struma Ovarii). Am J Surg Pathol 2007;31:1337-1343.

20 Lee JH, Lee ES, Kim YS. Clinicopathologic significance of Braf V600e mutation in papillary carcinomas of the thyroid: a meta-analysis. Cancer 2007;110: 38-46.

21 Xing M, Westra WH, Tufano RP, et al. Braf mutation predicts a poorer clinical prognosis for papillary thyroid cancer. J Clin Endocrinol Metab 2005;90: 6373-6379.

$22 \mathrm{Xu}$ X, Quiros RM, Gattuso P, et al. High prevalence of Braf gene mutation in papillary thyroid carcinomas and thyroid tumor cell lines. Cancer Res 2003;63: 4561-4567.

23 Delellis RA, Lloyd RV, Heitz PU, et al. Pathology and Genetics of Tumours of Endocrine Organs. IARC Press: Lyon, 2004.

24 Jin L, Sebo TJ, Nakamura N, et al. Braf mutation analysis in fine needle aspiration (Fna) cytology of the thyroid. Diagn Mol Pathol 2006;15:136-143.

25 Nakamura N, Carney JA, Jin L, et al. Rassf1a and Nore1a methylation and Brafv600e mutations in thyroid tumors. Lab Invest 2005;85:1065-1075.

26 Edge SB, Byrd DR, Compton CC, et al. AJCC Cancer Staging Manual, 7th edn. Springer: New York, London, 2009.

27 Patel KN, Shaha AR. Poorly differentiated and anaplastic thyroid cancer. Cancer Control 2006;13:119-128.

28 Garcia-Rostan G, Camp RL, Herrero A, et al. Beta-Catenin dysregulation in thyroid neoplasms: down-regulation, aberrant nuclear expression, And Ctnnb1 Exon 3 Mutations are markers for aggressive tumor phenotypes and poor prognosis. Am J Pathol 2001;158:987-996.

29 Garcia-Rostan G, Tallini G, Herrero A, et al. Frequent mutation and nuclear localization of beta-catenin in anaplastic thyroid carcinoma. Cancer Res 1999;59: 1811-1815.

30 Lazzereschi D, Sambuco L, Carnovale Scalzo C, et al. Cyclin D1 and Cyclin E expression in malignant thyroid cells and in human thyroid carcinomas. Int J Cancer 1998;76:806-811.

31 Tallini G, Garcia-Rostan G, Herrero A, et al. Downregulation of P27kip1 and Ki67/Mib1 labeling index support the classification of thyroid carcinoma into prognostically relevant categories. Am J Surg Pathol 1999;23:678-685.

32 Wang S, Lloyd RV, Hutzler MJ, et al. The role of cell cycle regulatory protein, Cyclin D1, in the progression of thyroid cancer. Mod Pathol 2000;13:882-887.

33 Hui PK, Chan JK, Cheung PS, et al. Columnar cell carcinoma of the thyroid. fine needle aspiration findings in a case. Acta Cytol 1990;34:355-358.

34 Fukunaga M, Shinozaki S, Miyazawa Y, et al. Columnar cell carcinoma of the thyroid. Pathol Int 1997;47: 489-492.

35 Genton CY, Dutoit M, Portmann L, et al. Pathologic fracture of the femur neck as first manifestation of a minute columnar cell carcinoma of the thyroid gland. Pathol Res Pract 1998;194:861-863.

36 Hirokawa M, Shimizu M, Fukuya T, et al. Columnar cell carcinoma of the thyroid: Mib-1 immunoreactivity as a prognostic factor. Endocr Pathol 1998;9:31-34.

37 Jayaram G. Cytology of columnar-cell variant of papillary thyroid carcinoma. Diagn Cytopathol 2000;22:227-229.

38 Barton CP III, Brennan JA, Lowry TR, et al. Columnar cell variant of papillary thyroid carcinoma. Ear Nose Throat J 2006;85:640, 643.

39 Kini H, Pai RR, Kalpana S. Solitary parotid metastasis from columnar cell carcinoma of the thyroid: a diagnostic dilemma. Diagn Cytopathol 2003;28:72-75.

40 Huang WT, Yang SF, Wang SL, et al. Encapsulated columnar-cell carcinoma of the thyroid: a case report. Kaohsiung J Med Sci 2005;21:241-244.

41 Watanabe K, Tsubota H, Himi T, et al. Columnar-cell carcinoma of the thyroid. Auris Nasus Larynx 2001;28:269-273.

42 Shimizu M, Hirokawa M, Manabe T. Tall cell variant of papillary thyroid carcinoma with foci of columnar cell component. Virchows Arch 1999;434:173-175.

43 Smith AE, Couch M, Argani P. Pathologic quiz case 1. papillary thyroid carcinoma (Ptc), combined tall cell and columnar variants. Arch Otolaryngol Head Neck Surg 1998;124:1170, 2.

44 Ylagan LR, Dehner LP, Huettner PC, et al. Columnar cell variant of papillary thyroid carcinoma. report of a case with cytologic findings. Acta Cytol 2004;48:73-77.

45 Zagar I, Vidergar-Kralj B, Schwarzbartl-Pevec AA, et al. Columnar cell thyroid carcinoma-diagnostic dilemmas and pitfalls. Nucl Med Rev Cent East Eur 2003;6: 155-158.

46 Yunta PJ, Ponce JL, Prieto M, et al. The importance of a tumor capsule in columnar cell thyroid carcinoma: a report of two cases and review of the literature. Thyroid 1999;9:815-819.

47 Perez F, Llobet M, Garijo G, et al. Fine-needle aspiration cytology of columnar-cell carcinoma of the thyroid: report of two cases with cytohistologic correlation. Diagn Cytopathol 1998;18:352-356. 
48 Putti TC, Bhuiya TA. Mixed columnar cell and tall cell variant of papillary carcinoma of thyroid: a case report and review of the literature. Pathology 2000;32:286-289.

49 Ciampi R, Nikiforov YE. Alterations of the braf gene in thyroid tumors. Endocr Pathol 2005;16:163-172.

50 Fugazzola L, Puxeddu E, Avenia N, et al. Correlation between B-Rafv600e mutation and clinico-pathologic parameters in papillary thyroid carcinoma: data from a multicentric italian study and review of the literature. Endocr Relat Cancer 2006;13:455-464.

51 Cohen Y, Xing M, Mambo E, et al. Braf mutation in papillary thyroid carcinoma. J Natl Cancer Inst 2003;95:625-627.

52 Begum S, Rosenbaum E, Henrique $\mathrm{R}$, et al. Braf mutations in anaplastic thyroid carcinoma: implications for tumor origin, diagnosis and treatment. Mod Pathol 2004;17:1359-1363.

53 Carr NJ, Mahajan H, Tan KL, et al. Serrated and nonserrated polyps of the colorectum: their prevalence in an unselected case series and correlation of braf mutation analysis with the diagnosis of sessile serrated adenoma. J Clin Pathol 2009;62:516-518.

54 Rajagopalan H, Bardelli A, Lengauer C, et al. Tumorigenesis: Raf/Ras oncogenes and mismatch-repair status. Nature 2002;418:934.

55 Pollock PM, Harper UL, Hansen KS, et al. High frequency of braf mutations in nevi. Nat Genet 2003;33:19-20.

56 Yuen ST, Davies H, Chan TL, et al. Similarity of the phenotypic patterns associated with Braf and Kras mutations in colorectal neoplasia. Cancer Res 2002;62:6451-6455.

57 Hall M, Peters G. Genetic alterations of cyclins, cyclindependent kinases, and cdk inhibitors in human cancer. Adv Cancer Res 1996;68:67-108.

58 Hunter T, Pines J. Cyclins and cancer. II: cyclin D and cdk inhibitors come of age. Cell 1994;79:573-582.

59 Katoh R, Bray CE, Suzuki K, et al. Growth Activity In Hyperplastic And Neoplastic Human Thyroid Determined By An Immunohistochemical Staining Procedure Using Monoclonal Antibody Mib-1. Hum Pathol 1995;26:139-146.

60 Khoo ML, Ezzat S, Freeman JL, et al. Cyclin D1 protein expression predicts metastatic behavior in thyroid papillary microcarcinomas but is not associated with gene amplification. J Clin Endocrinol Metab 2002;87: 1810-1813.

61 Letsas KP, Frangou-Lazaridis M, Skyrlas A, et al. Transcription factor-mediated proliferation and apoptosis in benign and malignant thyroid lesions. Pathol Int 2005;55:694-702.

62 Muro-Cacho CA, Holt T, Klotch D, et al. Cyclin D1 expression as a prognostic parameter in papillary carcinoma of the thyroid. Otolaryngol Head Neck Surg 1999;120:200-207.

63 Saltman B, Singh B, Hedvat CV, et al. Patterns of expression of cell cycle/apoptosis genes along the spectrum of thyroid carcinoma progression. Surgery 2006;140:899-905.

64 Wang S, Wuu J, Savas L, et al. The role of cell cycle regulatory proteins, Cyclin D1, Cyclin E, and P27 in thyroid carcinogenesis. Hum Pathol 1998;29:1304-1309.
65 Tetsu O, Mccormick F. Beta-catenin regulates expression of cyclin D1 in colon carcinoma cells. Nature 1999;398:422-426.

66 Lantsov D, Meirmanov S, Nakashima M, et al. Cyclin D1 overexpression in thyroid papillary microcarcinoma: its association with tumour size and aberrant beta-catenin expression. Histopathology 2005;47: 248-256.

67 Ishigaki K, Namba H, Nakashima M, et al. Aberrant localization of beta-catenin correlates with overexpression of its target gene in human papillary thyroid cancer. J Clin Endocrinol Metab 2002;87:3433-3440.

68 Siironen P, Nordling S, Louhimo J, et al. Immunohistochemical expression of Bcl-2, Ki-67, and P21 in patients with papillary thyroid cancer. Tumour Biol 2005;26:50-56.

69 Coqueret O. Linking cyclins to transcriptional control. Gene 2002;299:35-55.

70 Donghi R, Longoni A, Pilotti S, et al. Gene P53 mutations are restricted to poorly differentiated and undifferentiated carcinomas of the thyroid gland. J Clin Invest 1993;91:1753-1760.

71 Fagin JA, Matsuo K, Karmakar A, et al. High prevalence of mutations of the P53 gene in poorly differentiated human thyroid carcinomas. J Clin Invest 1993;91:179-184.

72 Ito T, Seyama T, Mizuno T, et al. Unique association of P53 mutations with undifferentiated but not with differentiated carcinomas of the thyroid gland. Cancer Res 1992;52:1369-1371.

73 Ito T, Seyama T, Mizuno T, et al. Genetic alterations in thyroid tumor progression: association with P53 gene mutations. Jpn J Cancer Res 1993;84:526-531.

74 Moore D, Ohene-Fianko D, Garcia B, et al. Apoptosis in thyroid neoplasms: relationship with P53 and Bcl-2 expression. Histopathology 1998;32:35-42.

75 Nakamura T, Yana I, Kobayashi T, et al. P53 gene mutations associated with anaplastic transformation of human thyroid carcinomas. Jpn J Cancer Res 1992;83:1293-1298.

76 Ron E, Kleinerman RA, Boice JD Jr, et al. A populationbased case-control study of thyroid cancer. J Natl Cancer Inst 1987;79:1-12.

77 Mctiernan AM, Weiss NS, Daling JR. Incidence of thyroid cancer in women in relation to reproductive and hormonal factors. Am J Epidemiol 1984;120:423-435.

78 Hiasa Y, Nishioka H, Kitahori Y, et al. Immunohistochemical analysis of estrogen receptors in 313 paraffin section cases of human thyroid tissue. Oncology 1993;50:132-136.

79 Chaudhuri PK, Prinz R. Estrogen receptor in normal and neoplastic human thyroid tissue. Am J Otolaryngol 1989;10:322-326.

80 Diaz NM, Mazoujian G, Wick MR. Estrogen-receptor protein in thyroid neoplasms. an immunohistochemical analysis of papillary carcinoma, follicular carcinoma, and follicular adenoma. Arch Pathol Lab Med 1991;115:1203-1207.

81 Tavangar SM, Monajemzadeh M, Larijani B, et al. Immunohistochemical study of oestrogen receptors in 351 human thyroid glands. Singapore Med J 2007;48:744-747. 